\title{
Analisis Determinan Keputusan Konsumen Muslim Membeli Green Product
}

\author{
Nanda Naufal Rofiza Haidar ${ }^{1 *}$, Achmad Firdaus ${ }^{2}$, Mukhamad Najib ${ }^{3}$ \\ ${ }^{1,2}$ Institut Agama Islam Tazkia Bogor, ${ }^{3}$ Institut Pertanian Bogor \\ 1naufalhaidar91@gmail.com, 2achmad.firdaus@tazkia.ac.id, 3najib@apps.ipb.ac.id \\ *Penulis Korespondensi
}

\begin{abstract}
The study aims to determine the effect of Collectivism, Eco-Literacy, Green Advertising, Spirituality and Environmental Concern on the intention to buy environmentally friendly products All Fresh on Indonesian Muslim consumers. The research consisted of three stages namely the study of literature. Then a field study was conducted by distributing questionnaires to 270 respondents. The analysis method used is Structural Equation Modeling (SEM) using AMOS. The results showed that the variables Collectivism, Eco-Literacy, Green Advertising and Spirituality showed a significant and positive effect on Environmental Concern. Furthermore, these variables show a significant and positive relationship to the attitude toward green products (ATGP) of Indonesian Muslim consumers.
\end{abstract}

Keywords: muslim consumers, consumer behavior, green product, SEM

\begin{abstract}
Abstrak
Penelitian bertujuan untuk mengetahui pengaruh Collectivisme, Eco-Literacy, Green Advertising, Spirituality dan Environmental Concern terhadap niat beli produk ramah lingkungan All Fresh pada konsumen muslim Indonesia. Penelitian terdiri dari tiga tahap yakni studi literatur. Kemudian dilakukan studi lapangan dengan menyebar kuesioner kepada 270 responden. Metode Analisis yang digunakan adalah Structural Equation Modeling (SEM) dengan menggunakan AMOS. Penelitian menunjukan bahwa variabel Collectivisme, Eco-Literacy, Green Advertising dan Spirituality menunjukan pengaruh yang signifikan dan positif terhadap Environmental Concern. Lebih lanjut lagi variable tersebut menunjukan hubungan yang signifikan dan positif terhadap attitude toward green product (ATGP) konsumen muslim Indonesia.
\end{abstract}

Kata kunci: Konsumen Muslim, Perilaku Konsumen, Produk Hijau, SEM

\section{Cara Mengutip:}

Haidar, N. N. R., Firdaus, A., Najib, M. (2020). Analisis Determinan Keputusan Konsumen Muslim Membeli Green Product. Esensi: Jurnal Bisnis dan Manajemen. Vol. 10 (1) : 19-30. DOI: http://doi.org/10.15408/ess. v10i1.13801 


\section{PENDAHULUAN}

Perkembangan industri memberikan dampak baik bagi manusia tetapi di sisi lain juga terkadang berdampak negatif bagi lingkungan. Saat ini mulai tumbuh kepedulian masyarakat terhadap isu lingkungan. Perusahaan sebagai penghasil produkpun berusaha memanfaatkan isu tersebut dalam kegiatan aktivitas bisnisnya (Chen dan Chang, 2012).

Lembaga Survey Global Nielsen (2014) menemukan bahwa konsumen di Asia lebih peduli dan sadar terhadap lingkungan dibandingkan dengan konsumen di Amerika Utara dan Eropa. Kesadaran tersebut mempengaruhi mereka dalam mengambil keputusan pembelian produk. Perusahaan yang mempunyai kesadaran tinggi terhadap lingkungan, akan lebih diminati produknya dibandingkan produsen yang rendah terhadap kesadaran pada lingkungan. Konsumen rela mengeluarkan uang yang lebih untuk mendapatkan produk hijau.

Umat Islam sebagai konsumen diharapkan mendukung kampanye perlindungan lingkungan ini. Terlebih sebagai seorang Muslim, konsumen memiliki tugas sebagai khalifah Allah di bumi. Manusia diberikan amanah oleh Allah untuk mengelola bumi dengan baik. Tugas pengelolaan bumi melalui kepedulian terhadap Green Consumerism

Green consumerism dan Muslim consumerism bermakna semakin kuatnya kesadaran konsumen terhadap haknya untuk mendapatkan produk yang baik, aman, dan ramah terhadap lingkungan. Walaupun pada kenyataannya produk yang di inginkan bukanlah produk yang benar-benar hijau, namun setidaknya produk tersebut dapat mengurangi tingkat kerusakan yang di timbulkan. Munculnya isu green consumerism membuat perusahaan mulai menerapkan strategi pemasaran yang mendukung Green Marketing (chen dan chang 2012).

Green Product merupakan sebuah fokus baru dalam bisnis, yaitu sebuah pendekatan pemasaran stratejik yang mulai menjadi perhatian para pelaku bisnis. Dengan kondisi ini maka para pelaku bisnis berhati-hati dalam mengambil keputusan yang terkait dengan lingkungan. Diantaranya pemilihan bakan baku, proses produksi, packaging, hingga cara beriklan. Hal ini karena perhatian terhadap isu lingkungan terlihat nyata dari meningkatnya pasar yang peduli terhadap lingkungan (Laroche et.al, 2001).

Green Product adalah produk yang ditandai dengan mempertimbangkan masalah daur ulang dan pembuangan limbah; penggunaan material yang didaur ulang dan dapat didaur ulang serta tidak berpolusi, atau tidak beracun; penggunaan energi, toksisitas manusia, dampak ekologis dan masalah berulang tiap tahap siklus proses; dan dampak akumulatip dari mekanisme penilaian dan peningkatan dalam siklus pengembangan produk (Chiou et al., 2011)

Alam et al. (2011) berpendapat bahwa muslim consumerism merupakan suatu aktivitas manusia yanng berkaitan dengan aktivitas membeli dan menggunakan produk barang dan jasa, dengan memperhatikan kaidah ajaran islam, dan berguna bagi kemaslahatan umat. Di seluruh dunia, pasar muslim yang berkembang pesat menarik bagi para pemasar (Razzaque dan Chaudhry, 2013).

Tingkat religiusitas konsumen muslim dapat mempengaruhi keputusan pembelian (Hassan, 2014). Hasan menjelaskan tentang peran nilai-nilai Islam pada niat beli produk hijau. Tingkat religiusitas yang tinggi pada konsumen muslim membuat mereka peka terhadap pembelian produk yang ramah lingkungan. Indonesia memilki jumlah penduduk muslim 
yang besar. Menurut sensus BPS (2010), terdapat sekitar 207,2 juta muslim yang tinggal di Indonesia. Namun demikian, penelitian tentang pola konsumsi muslim Indonesia masih terbatas. Pemahaman yang tepat antara hubungan religiusitas Muslim dengan preferensi produk dapat membantu pemasar untuk menentukan strategi yang tepat untuk produk hijau di Indonesia.

Patut diduga bahwa minat beli produk hijau atau Attitude Toward Green Product (ATGP) oleh konsumen muslim dipengaruhi oleh Environmental Concern atau sikap kepedulian terhadap lingkungan. ATGP merupakan sikap yang mewakili kecenderungan untuk bertindak secara positif atau negatip terhadap objek spesifik yang terkait dengan situasi yang dihadapi oleh individu (Moser, 2015). ATGP mencerminkan kecenderungan konsumen untuk bertindak secara lebih baik atau tidak lebih baik dalam menyikapi produk hijau (Chen, 2010).

ATGP dapat memainkan peran penting dalam memengaruhi niat konsumen untuk membeli produk ramah lingkungan. Sebagai contoh, pengamatan dalam penelitian oleh Cheah dan Phau (2011) pada konsumen Australia menunjukkan bahwa konsumen yang memiliki kesadaran lingkungan yang baik rela membayar lebih untuk pembelian produk hijau,karena produk hijau tidak memberikan dampak buruk bagi lingkungan dan produk tersebut memberikan perhatian lebih terhadap lingkungan.Tang dan Lam (2017), dalam studi mereka pada konsumen Cina, menunjukkan bahwa ATGP berpengaruh positif dalam keinginan pembelian produk hijau/Green Product.

Environmental Concern bisa timbul dari diri seorang konsumen muslim ketika konsumen tersebut memiliki sikap Collectivisme dan Eco-Literacy. Environmental Concern muncul Ketika individu peka terhadap lingkungan, sedikit perubahan dalam keadaan lingkungan dapat merangsang mereka untuk secara aktif berpartisipasi dalam pelestarian lingkungan program (Hassan, 2014). Dengan keadaan lingkungan seperti ini yang mana banyak kerusakan yang terjadi pada lingkungan, individu diharapkan memiliki kesadaran terhadap inisiatif produk hijau.

Dengan demikian, diharapkan konsumen dengan EC tinggi akan mengubah pola konsumsi mereka demi lingkungan (Hassan, 2014). Tang et al. (2014) menyelidiki hubungan langsung EC dengan ATGP pada konsumen Tiongkok dan menyarankan bahwa EC adalah faktor kunci yang mempengaruhi sikap konsumen terhadap produk ramah lingkungan. Muralidharan et al. (2015) membandingkan preferensi hijau konsumen muda dari India dan Cina. Menurut temuan mereka, EC secara signifikan memengaruhi keputusan pembelian hijau konsumen India dan Cina.

Kolektivisme merujuk fokus pada kesejahteraan masyarakat dan mempertimbangkan dimana pencapaian tujuan kelompok lebih penting daripada sekadar pencapaian keuntungan individu (choe et al.,2012). Akehurst et al. (2012), dalam studinya tentang konsumen portugis, menegaskan bahwa kepedulian konsumen terhadap kesejahteraan orang lain akan meningkatkan rasa kepedulian terhadap lingkungan. Nguyen et al. (2017) juga menyelidiki pengaruh nilai-nilai budaya pada keputusan hijau konsumen Vietnam. Mereka berpendapat bahwa kolektivisme yang tinggi antara konsumen menghasilkan sikap yang positif terhadap lingkungan. 
Selain itu, penelitian sebelumnya juga telah meneliti hubungan langsung collectivism dengan keputusan pembelian konsumen hijau. Sebagai contoh, Laroche et al. (2001) menyelidiki hubungan ini untuk konsumen di AS. Mereka menyarankan bahwa konsumen dengan keyakinan kolektivisme lebih cenderung membeli produk ramah lingkungan. Demikian pula, Cheah dan Phau (2011) meneliti hubungan kolektivisme dengan ATGP untuk konsumen Australia. Mereka juga mengungkapkan hubungan positif antara keduanya yaitu kolektivisme dan ATGP.

Eco-literacy menunjukkan kemampuan seseorang untuk mengidentifikasi dan memahami simbol, konsep dan perilaku yang berkaitan dengan lingkungan (Laroche et al.1996). Bahkan, EL mengacu pada pengetahuan yang membantu dalam mengembangkan pemahaman di antara individu- individu bahwa sumber daya yang disediakan oleh alam dapat habis dan perlu dilindungi untuk menjaga planet ini menjadi tempat yang aman untuk generasi sekarang dan yang akan datang (Laroche et al., 2001).

Hassan (2014) dalam penelitiannya mengemukakan bahwa naiknya EC baru-baru ini di kalangan konsumen adalah karena peningkatan pengetahuan mereka tentang masalah lingkungan. Kirmani dan Khan (2016), berusaha menjelaskan alasan keterkaitan positif antara EL dan sensitivitas lingkungan dalam pernyataan mereka bahwa pendidikan memungkinkan konsumen untuk memahami alasan di balik masalah ekologis (global warming, penipisan ozon, rain acid, penguraian limbah plastik) dan dampak buruknya pada generasi sekarang dan generasi mendatang.

Kurangnya pendidikan, di sisi lain, membatasi pemahaman konsumen tentang masalah lingkungan dan dapat bertindak sebagai penghalang dalam mengembangkan kesadaran lingkungan di kalangan konsumen (Nath et al., 2013).

Pentingnya EL dalam memprediksi ATGP juga didukung oleh Boo dan Park (2013) dalam pengamatan mereka bahwa kenaikan tingkat EL berkontribusi pada peningkatan niat individu China untuk terlibat dalam perilaku peduli lingkungan. Dalam analisis yang lebih rinci tentang konsumen Australia, Ogbeide et al. (2015) mengemukakan bahwa tingkat EL yang lebih tinggi memengaruhi konsumen bersedia untuk membayar lebih mahal pada produk ramah lingkungan.

Green Advertising adalah pesan promosi yang mungkin menarik bagi kebutuhan dan keinginan kosnsumen yang peduli lingkungan (Gandhi and Rao., 2015). Zinkhan \& Carlson (1995) mendefinisikan iklan hijau sebagai daya tarik yang mencoba memenuhi kebutuhan dan aspirasi konsumen terkait dengan Environmental Concern dan masalah kesehatan dari berbagai sudut pandang termasuk ekologi, keberlanjutan, dan pesan bebas polusi.

Periklanan hijau tidak hanya memengaruhi sikap konsumen terhadap lingkungan, penelitian oleh Zhao (2014) menemukan kredibilitas klaim iklan ramah lingkungan memiliki peran penting dalam memengaruhi niat pembelian konsumen dari produk ramah lingkungan. Hal ini juga didukung oleh penelitian yang dilakukan oleh Ahmad et al. (2010) yang menunjukkan bahwa iklan lingkungan berdampak pada niat pembelian konsumen menjadi produk ramah lingkungan. Sementara Rahbar dan Wahid (2011) menemukan iklan hijau membantu konsumen membuat keputusan pembelian, tetapi tidak mempengaruhi perilaku konsumen dalam membeli produk ramah lingkungan. 
Faktor lain yang mempengaruhi pembelian produk hijau adalah spiritualitas yang didefinisikan sebagai sebuah keterhubungan dengan Tuhan, yang pada akhirnya menimbulkan suatu makna, tujuan dan misi dalam hidup. Parsian dan Dunning (2009), yang telah mengembangkan kuesioner spiritualitas mendefinisi spiritualitas sebagai pencarian makna dalam kehidupan, aktualisasi diri dan koneksi dengan diri sendiri (inner-self), orang lain dan keseluruhannya dan menyatakan bahwa definisi tersebut dapat diterapkan pada orang yang religius maupun yang tidak religius.

Rehman (2010) dalam penelitiannya menjelaskan dimana spirituality secara operasional didefinisikan memiliki lima dimensi yaitu; ideologis, ritualistik, intelektual, konsekuensial, dan eksperimental. Dimensi ideologis meliputi keyakinan keseluruhan yang terkait dengan suatu agaman. Misalnya, kepercayaan tentang tuhan, nabi, nasib dll. Dimensi ritualistik seperti tindakan atau hal yang telah diatur dalam agama seperti; Sholat, puasa, zakat, haji dll. Dimensi intelektual merujuk pada pengetahuan sesorang tentang agama seperti mengikuti perintah agama dalam semua hal, termasuk didalamnya menjaga kelestarian lingkungan. Dimensi konsekuensial merujuk pada pentingnya agama. Adapun dimensi eksperimental menjelaskan tentang kepraktisan agama.

Salah satu alasan seseorang melakukan pembelian terhadap produk adalah karena Spirituality. Spirituality di sini berfungsi sebagai faktor pendorong gaya hidup seorang konsumen, yang dapat mempengaruhi pilihan konsumen terhadap suatu produk. Spirituality adalah sesuatu hal yang ada hubungannya dengan pengalaman, ritual agama dan juga kepercayaan. Dalam upaya pengambilan keputusan pembelian, seorang konsumen muslim menggunakan keyakinan di dalam hatinya untuk membeli produk yang ditawarkan produsen. Pembelian produk ramah lingkungan dipengaruhi oleh religiusitas yang dimiliki oleh seorang konsumen. Hasil penelitian ini didukung oleh Alam et al. (2011), Islam dan Chandrasekaran (2016), Bhuian dan Sujeet (2018) bahwa terdapat hubungan antara religiusitas dengan perilaku pembelian.

\section{METODE}

Penelitian ini menggunakan data primer dan sekunder. Data sekunder didapatkan melalui kajian literatur tentang gambaran umum tentang strategi marketing dan produk yang di hasilkan melalui buku-buku terkait, jurnal, media massa, internet, dan penelitian terdahulu yang terkait.

Data primer dihasilkan melalui kuesioner yang disebar kepada setiap pelanggan All Fresh lokasi penelitian. Jumlah responden dalam penelitian ini adalah 270 responden dengan kriteria: (1) Pelanggan yang pernah membeli produk All Fresh. (2) Pelanggan tersebut mengetahui bahwa All Fresh merupakan perusahaan pangan yang ramah lingkungan (3) berusia 15 sampai $\geq 41$ tahun. (4) berpenghasilan minimal tiga juta rupiah. Kriteria ini digunakan untuk memperlihatkan bahwa sampel yang menjadi responden dari All Fresh memiliki pertimbangan yang cukup matang dilihat dari seberapa sering dan aware mereka untuk menjadi konsumen loyal di All Fresh Indonesia. 
Tabel 1 Nilai Goodness of Fit yang dapat diterima

\begin{tabular}{ll}
\hline \multicolumn{1}{c}{ Goodness of Fit (GoF) } & Cut of Value \\
\hline Absolute Fit Measure & \\
Root Mean Square Error of Approximation (RMSEA) & $\leq 0.08$ good fit \\
Root Mean Square Residual (RMR) & $<0,05$ good fit \\
Goodness of Fit Index (GFI) & GFI $\geq 0,90$ good fit \\
Incremental Fit Measure & \\
Adjusted Goodness of Fit Index (AGFI) & AGFI $\geq 0,90$ \\
Comparative Fit Index (CFI) & $\mathrm{CFI} \geq 0,90$ good fit \\
Normed Fit Index (NFI) & $\mathrm{NFI} \geq 0,90$ good fit \\
Relative Fit Index (RFI) & $\mathrm{RFI} \geq 0,90$ good fit \\
Parsimonious Fit Measure & \\
Parsimonious Normed of Fit Index (PNFI) & Semakin besar semakin baik \\
Parsimonious Goodness of Fit Index (PGFI) & Semakin besar semakin baik \\
\hline
\end{tabular}

Metode yang digunakan dalam penelitian ini adalah Structural Equation Model (SEM) adalah AMOS. Dalam analisis SEM, tidak ada alat uji statistik tunggal untuk menguji hipotesis mengenai model (Hair et al., 2010). Tetapi berbagai fit index yang digunakan untuk mengukur derajat kesesuaian antara model yang disajikan.

\section{HASIL DAN PEMBAHASAN}

Analisis dalam penelitian ini menggunakan metode statistik Stuctural Equation Model (SEM). Pada prinsipnya, model struktural bertujuan untuk menguji hubungan sebab akibat dari hubungan variabel sehingga jika salah satu variabel diubah, maka terjadi perubahan pada variabel yang lain. Selain itu analisis Stuctural Equation Model (SEM) bertujuan untuk mengestimasi beberapa persamaan regresi terpisah akan tetapi masing-masing mempunyai hubungan simultan atau bersamaan.

Dalam analisis ini dimungkinkan terdapat beberapa variabel dependen, dan variabel ini dimungkinkan menjadi variabel independen bagi variabel dependen yang lainnya. Dalam studi ini, data diolah dengan menggunakan software khusus untuk analisis SEM yaitu AMOS.

Tabel 2 Hasil Pengujian Kelayakan Model

\begin{tabular}{cccc}
\hline Goodness of Fit & Cut off value & Estimasi & Keterangan \\
\hline$X^{2}$-Chi-square (df=335) & 378.68 & 579,872 & Tidak Fit \\
CMIN/DF & $\leq 2.00$ & 1,731 & Fit \\
Probabilitas & $\geq 0.05$ & 0,000 & Tidak Fit \\
Root Mean Square Error & $\leq 0.08$ & 0.052 & Fit \\
of Approximation & & & Acceptable \\
GFI & $\geq 0.90$ & 0.865 & Acceptable \\
AGFI & $\geq 0.90$ & 0.837 & Fit \\
TLI & $\geq 0.95$ & 0.952 & Fit \\
CFI & $\geq 0.95$ & 0.958 & Fit \\
NFI & $\geq 0.90$ & 0.906 & \\
\hline
\end{tabular}


Pengujian model SEM bertujuan untuk melihat kesesuaian model. Hasil uji kelayakan model selengkapnya disajikan pada tabel 2 dan Hasil model selengkapnya disajikan pada gambar 1.

Tabel 3 Regression weight Pengujian Hipotesis Model

\begin{tabular}{|c|c|c|c|c|c|c|c|}
\hline \multicolumn{3}{|c|}{ Jalur } & \multirow{2}{*}{$\begin{array}{c}\text { Estimate } \\
0,277\end{array}$} & \multirow{2}{*}{$\begin{array}{c}\text { S.E. } \\
, 066\end{array}$} & \multirow{2}{*}{$\begin{array}{c}\text { C.R. } \\
4,208\end{array}$} & \multirow{2}{*}{$\begin{array}{c}\mathbf{P} \\
.000\end{array}$} & \multirow{2}{*}{$\begin{array}{c}\text { Keterangan } \\
\text { Signifikan }\end{array}$} \\
\hline EC & $<---$ & Collectivisme & & & & & \\
\hline EC & $<--$ & ECO & 0,282 &, 067 & 4,189 & .000 & Signifikan \\
\hline EC & $<---$ & GA & 0,185 & ,056 & 3,322 & .000 & Signifikan \\
\hline EC & $<--$ & Spirituality & 0,229 &, 074 & 3,096 & ,002 & Signifikan \\
\hline ATGP & $<--$ & EC & 0,301 & ,083 & 3,610 & .000 & Signifikan \\
\hline ATGP & $<--$ & Collectivisme & 0,143 & ,071 & 2,009 & ,045 & Signifikan \\
\hline ATGP & $<--$ & ECO & 0,161 & ,072 & 2,235 & ,025 & Signifikan \\
\hline ATGP & $<--$ & GA & 0,169 & ,059 & 2,841 & ,004 & Signifikan \\
\hline ATGP & $<---$ & Spirituality & 0,243 & ,079 & 3,083 & ,002 & Signifikan \\
\hline
\end{tabular}

Sumber : Data diolah (2019)

Hasil output kausalitas model Structural Equation Modeling selengkapnya disajikan pada tabel 3.

Hasil pengujian statistik pada hipotesis pertama menunjukkan bahwa nilai parameter estimasi collectivisme terhadap EC sebesar 0.277 yamg menunjukan berpengaruh positif signifikan karena nilai CR sebesar 4.208 dan nilai signifikansi 0.000. Berdasarkan hasil tersebut maka dapat disimpulkan bahwa hipotesis kedua yang menyatakan terdapat pengaruh yang signifikan collectivisme terhadap EC terbukti dan dapat diterima pada tingkat signifikansi alpha 5\%. Temuan ini mendukung pengamatan Cho et al. (2012) menunjukan bahwa sikap konsumen terhadap lingkungan secara positif dipengaruhi secara horizontal, yaitu penekanan tujuan kelompok bersama dengan tujuan pribadi dan collectivism fokus pada perilaku kelompok, korporatif, menjaga hubungan baik dan saling membutuhkan. Akehurst et al. (2012), dalam studinya tentang konsumen portugis, menegaskan bahwa kepedulian konsumen terhadap kesejahteraan orang lain juga dapat meningkatkan kepedulian mereka terhadap lingkungan. Nguyen et al. (2017) juga menyelidiki pengaruh nilai-nilai budaya pada keputusan hijau konsumen Vietnam. Mereka berpendapat bahwa kolektivisme yang tinggi antara konsumen menghasilkan sikap yang positif terhadap lingkungan.

Hasil pengujian statistik pada hipotesis kedua menunjukkan bahwa nilai parameter estimasi kolektivisme terhadap ATGP sebesar 0.143, nilai CR 2.009 dan p-signifikansi 0.045 sehingga kolektivisme signifikan berpengaruh positif terhadap ATGP. Berdasarkan hasil tersebut maka dapat disimpulkan bahwa hipotesis pertama yang menyatakan terdapat pengaruh yang signifikan kolektivisme terhadap ATGP terbukti dan diterima pada tingkat signifikansi alpha 5\%. Penelitian sebelumnya telah meneliti hubungan langsung kolektivisme dengan keputusan pembelian konsumen hijau. Sebagai contoh, Laroche et al. (2001) menyelidiki hubungan ini untuk konsumen di AS. Mereka menjelaskan bahwa konsumen 
dengan keyakinan kolektivisme lebih cenderung membeli produk ramah lingkungan. Demikian pula, Cheah dan Phau (2011) meneliti hubungan kolektivisme dengan ATGP untuk konsumen Australia. Mereka juga mengungkapkan hubungan positif antara keduanya yaitu kolektivisme dan ATGP.

\section{Gambar 1 Model SEM}

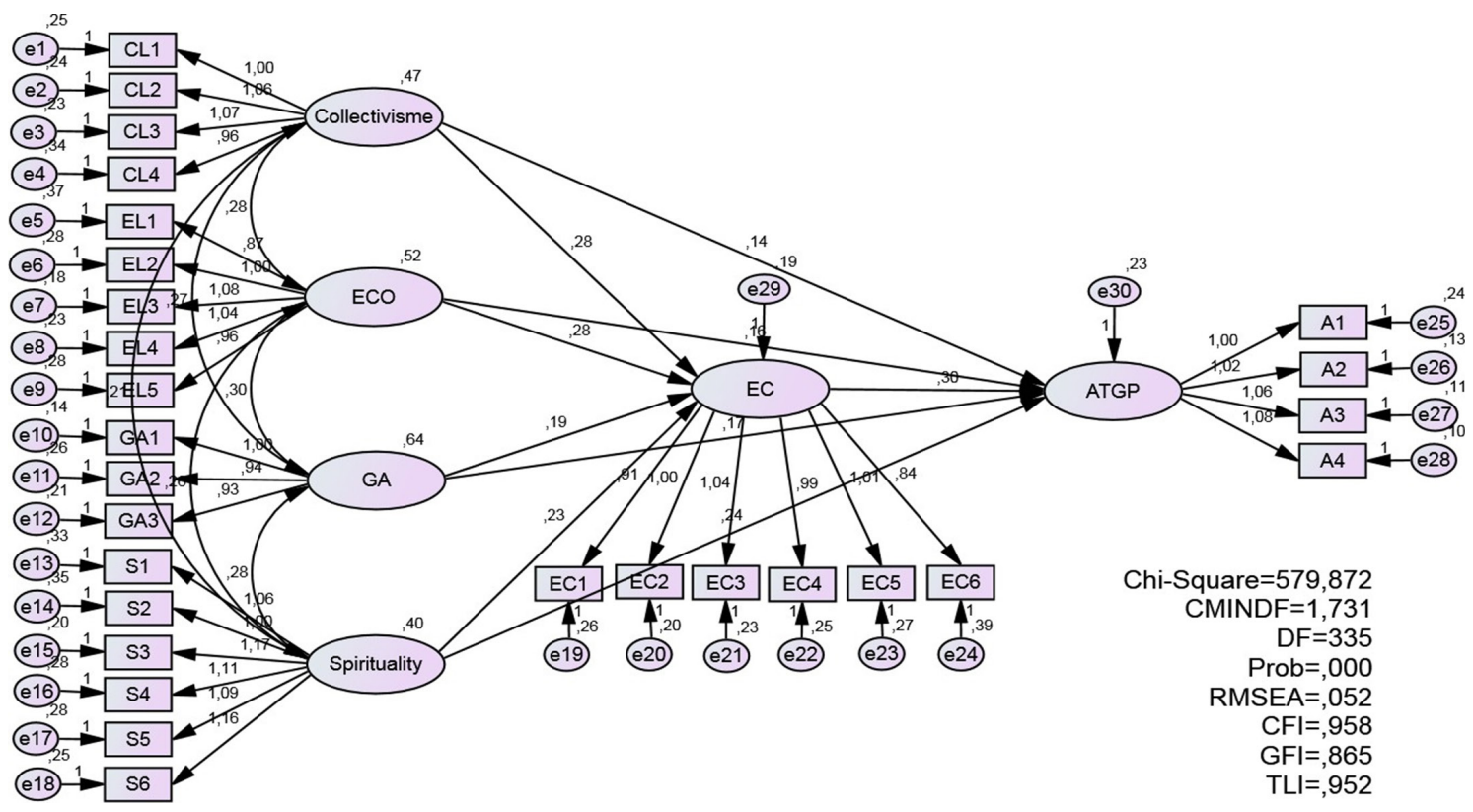

Hasil pengujian statistik pada hipotesis ketiga menunjukkan bahwa nilai parameter estimasi ECO terhadap EC sebesar 0.282 yamg menunjukan berpengaruh signifikan karena nilai CR sebesar 4.189 dan nilai signifikansi 0.000. Berdasarkan hasil tersebut maka dapat disimpulkan bahwa hipotesis ketiga yang menyatakan terdapat pengaruh yang signifikan ECO terhadap EC terbukti dan diterima pada tingkat signifikansi alpha 5\%. Pengetahuan diperlukan untuk membuat keputusan terkait dengan perlindungan lingkungan. Cheah dan Phau (2011) meneliti hubungan EL dengan sikap konsumen terhadap lingkungan. Hubungan positif antara kedua hal tersebut mendukung gagasan bahwa kenaikan tingkat EL meningkatkan sensitivitas lingkungan di kalangan konsumen. Lebih khusus, Hassan (2014) dalam penelitiannya mengemukakan bahwa kenaikan EC di kalangan konsumen adalah karena peningkatan pengetahuan mereka tentang masalah lingkungan. Kirmani dan Khan (2016), berusaha menjelaskan alasan keterkaitan positif antara EL dan sensitivitas lingkungan dalam pernyataan mereka bahwa pendidikan memungkinkan konsumen untuk memahami alasan di balik masalah ekologis dan dampak buruknya pada generasi sekarang dan generasi mendatang.

Hasil pengujian statistik pada hipotesis keempat menunjukkan bahwa nilai parameter estimasi ECO ke ATGP sebesar 0.161 yang menunjukan berpengaruh signifikan karena nilai CR sebesar 2.235 dan nilai signifikansi 0.025. Berdasarkan hasil tersebut maka dapat disimpulkan bahwa hipotesis ketiga yang menyatakan terdapat pengaruh yang signifikan variabel ECO terhadap ATGP terbukti dan diterima pada tingkat signifikansi alpha 5\%. Pentingnya EL dalam memprediksi ATGP didukung oleh Boo dan Park (2013) dalam pengamatan mereka 
bahwa kenaikan tingkat EL berkontribusi pada peningkatan niat individu China untuk terlibat dalam perilaku peduli lingkungan. Dalam analisis yang lebih rinci tentang konsumen Australia, Ogbeide et al. (2015) mengemukakan bahwa tingkat EL yang lebih tinggi memengaruhi konsumen bersedia untuk membayar lebih mahal pada produk ramah lingkungan.

Hasil pengujian statistik pada hipotesis kelima menunjukkan bahwa nilai parameter estimasi GA terhadap EC sebesar 0.185 yamg menunjukan berpengaruh signifikan karena nilai CR sebesar 3.322 dan nilai signifikansi 0.000 . Berdasarkan hasil tersebut maka dapat disimpulkan bahwa hipotesis keenam yang menyatakan terdapat pengaruh yang signifikan GA terhadap EC terbukti dan diterima pada tingkat signifikansi alpha 5\%. Zinkhan \& Carlson (1995) mendefinisikan iklan hijau sebagai daya tarik yang mencoba memenuhi kebutuhan dan aspirasi konsumen terkait dengan Environmental Concern dan masalah kesehatan dari berbagai sudut pandang termasuk ekologi, keberlanjutan, dan pesan bebas polusi.

Hasil pengujian statistik pada hipotesis keenam menunjukkan bahwa nilai parameter estimasi GA terhadap ATGP sebesar 0.169 yang menunjukan berpengaruh signifikan karena nilai CR sebesar 2.841 dan nilai signifikansi 0.004 . Berdasarkan hasil tersebut maka dapat disimpulkan bahwa hipotesis kelima yang menyatakan bahwa terdapat pengaruh yang signifikan GA terhadap ATGP terbukti dan dapat diterima pada tingkat signifikansi 5\%. Periklanan hijau tidak hanya memengaruhi sikap konsumen terhadap lingkungan, penelitian oleh Zhao (2014) menemukan kredibilitas klaim iklan ramah lingkungan memiliki peran penting dalam memengaruhi niat pembelian konsumen dari produk ramah lingkungan. Hal ini juga didukung oleh penelitian yang dilakukan oleh Ahmad et al. (2010) yang menunjukkan bahwa iklan lingkungan berdampak pada niat pembelian konsumen menjadi produk ramah lingkungan. Sementara Rahbar dan Wahid (2011) menemukan iklan hijau membantu konsumen membuat keputusan pembelian, tetapi tidak mempengaruhi perilaku konsumen dalam membeli produk ramah lingkungan.

Hasil pengujian statistik pada hipotesis ketujuh menunjukkan bahwa nilai parameter estimasi spirituality terhadap EC sebesar 0.229 yamg menunjukan berpengaruh signifikan karena nilai CR sebesar 3.096 dan nilai signifikansi 0.002. Berdasarkan hasil tersebut maka dapat disimpulkan bahwa hipotesis kedelapan yang menyatakan terdapat pengaruh yang signifikan spirituality terhadap EC terbukti dan diterima pada tingkat signifikansi alpha 5\%. Hasil penelitian ini sesuai dengan hasil penelitian yang dilakukan sebelumnya oleh Rehman (2010) yang menemukan bahwa spirituality berpengaruh positif dan significant terhadap environmental concern. Artinya ketika sesorang memiliki spiritualitas yang tinggi maka sikap terhadap lingkungan akan tinggi juga.

Hasil pengujian statistik pada hipotesis kedelapan menunjukkan bahwa nilai parameter estimasi spirituality terhadap ATGP sebesar 0.243 yang menunjukan berpengaruh signifikan karena nilai CR sebesar 3.083 dan nilai signifikansi 0.002. Berdasarkan hasil tersebut maka dapat disimpulkan bahwa hipotesis ketujuh yang menyatakan bahwa terdapat pengaruh yang signifikan spirituality terhadap ATGP terbukti dan dapat diterima pada tingkat signifikansi 5\%. Salah alasan seseorang melakukan pembelian terhadap produk adalah karena Spirituality. Spirituality di sini berfungsi sebagai faktor pendorong gaya hidup seorang konsumen, yang dapat mempengaruhi pilihan konsumen terhadap suatu produk. Religiusitas adalah sesuatu hal yang ada hubungannya dengan pengalaman, ritual agama dan juga kepercayaan. Dalam 
upaya pengambilan keputusan pembelian, seorang konsumen muslim menggunakan keyakinan di dalam hatinya untuk membeli produk yang ditawarkan produsen. Pembelian produk ramah lingkungan dipengaruhi oleh religiusitas yang dimiliki oleh seorang konsumen. Hasil penelitian ini didukung oleh Alam et al. (2011), Islam dan Chandrasekaran (2016), Bhuian et Al. (2018) bahwa terdapat hubungan antara religiusitas dengan perilaku pembelian.

Hasil pengujian statistik pada hipotesis kesembilan menunjukkan bahwa nilai parameter estimasi EC terhadap ATGP sebesar 0.301 yang menunjukan berpengaruh signifikan karena nilai CR sebesar 3.610 dan nilai signifikansi 0.000. Berdasarkan hasil tersebut maka dapat disimpulkan bahwa hipotesis kesembilan yang menyatakan bahwa terdapat pengaruh yang signifikan EC terhadap ATGP terbukti dan dapat diterima pada tingkat signifikansi 5\%. Ketika individu peka terhadap lingkungan, sedikit perubahan dalam keadaan lingkungan dapat merangsang mereka untuk secara aktif berpartisipasi dalam pelestarian lingkungan program (Hassan, 2014). Dengan keadaan lingkungan seperti ini yang mana banyak kerusakan yang terjadi pada lingkungan, individu diharapkan memiliki kesadaran terhadap inisiatif produk hijau. Dengan demikian, diharapkan konsumen dengan EC tinggi akan mengubah pola konsumsi mereka demi lingkungan (Hassan, 2014).

\section{KESIMPULAN}

Hasil penelitian ini menunjukan bahwa variable Collectivism, Eco-Literacy, Green Advertising, dan Spirituality menunjukan pengaruh yang signifikan dan positif terhadap Environmental Concern. Hal ini menunjukan ketika keempat variable tersebut tinggi maka akan semakin mendorong sikap peduli terhadap lingkungan yang semakin tinggi pula. Variable Collectivism, Eco-Literacy, Green Advertising, dan Spirituality juga menunjukan hubungan yang positif dan signifikan terhadap ATGP hal ini menunjukan bahwa terdapat hubungan langsung antara Variable Collectivism, Eco-Literacy, Green Advertising, dan Spirituality dengan ATGP. Environmental Concern berpengaruh positif dan signifikan terhadap ATGP hal ini menunjukkan bahwa konsumen yang memiliki kepedulian yang kuat terhadap lingkungan lebih cenderung ke arah konsumsi produk hijau.

\section{PUSTAKA ACUAN}

Ahmad, H., Ahmad, K., \& Ali, S. I. (2010). Factors in environmental advertising influencing. European Journal of Scientific Research Vol. 48 No.2 217-226, pp.217-226.

Akehurst, G., Gonçalves, H. M., \& Afonso, C. (2012). Re-examining green purchase behaviour and the green consumer profile: New evidences. Management Decision Vol. 50 No. 5, pp. 972-988.

Alam, S. S., Mohd, R., \& Hisham, B. (2011). Is religiosity an important Muslim Consumer behavior determinant on Muslim consumer behaviour in Malaysia? Journal of Islamic Marketing Vol. 2 No. 1, pp. 83-96.

Ankit, G., \& Mayur, R. (2015). Green Marketing: Impact of Green Advertising on Consumer Purchase Intention.

Ateeq-ur-Rehman. (2010). The relationship between religiosity and new product adoption. Journal of Islamic Marketing Vol. 1 No. 1, pp. 63-69. 
Bhuian, S. N., Sharma, S. K., Butt, I., \& Ahmed, Z. U. (2018). Antecedents and pro-environmental. Journal of Consumer Marketing Vol. 35 No. 3 pp. 287-299.

Boo, S., \& Park, E. (2013). An examination of green intention: the effect of environmental knowledge and educational experiences on meeting planners' implementation of green meeting practices. Journal of Sustainable Tourism, Vol. 21 No. 8, pp. 1129-1147.

Chai, L., \& Chen, T. (2009). Religiosity as an antecedent of attitude towards green products: an exploratory research on young Malaysian consumers. ASEAN Marketing Journal Vol. 1 No. 1, pp. 29-36.

Cheah, I., \& Phau, I. (2011). Attitudes towards environmentally friendly products: the influence of ecoliteracy, interpersonal influence and value orientation. Marketing Intelligence and Planning, Vol. 29 No. 5, pp. 452-472.

Chen, T., \& Chai, L. (2010). Attitude towards the environment and green products: consumers' perspective. Management Science and Engineering, Vol. 4 No. 2, pp. 27-39.

Chen, Y., \& Chang, C. (2012). Enhance green purchase intentions the roles of green perceived value, green perceived risk and green trust. Journal of Management Decision Vol. 50. No. 3., pp. 502-520.

Chiou, T., Chan, H., Lettice, F., \& Chung, S. (2011). The influence of greening the suppliers and green innovation on environmental performance and competitive advantage in Taiwan. Transportation Research Part E, Vol. 47 No. 6, November 2011, pp. 822-36.

Cho, Y.-N., Rapert, M. I., Lee., H. J., Thyroff, P., \& Park, S.-Y. (2012). To be or not to be green: Exploring individualism and collectivism as antecedents of environmental behavior. Journal of Business Research Vol. 66 No. 8, pp. 1052-1059.

Hair., J. F., Black, W. C., Babin, B. J., \& Anderson, R. E. (2010). Multivariate Data Analysis Seventh Edition. New Jersey: Pearson.

Hassan, S. H. (2014). The role of Islamic values on green purchase intention. Journal of Islamic Marketing Vol. 5 No. 3, pp. 379-395.

Islam, T., \& Chandrasekaran, U. (2016). Effect of religiosity on ecologically conscious consumption behaviour. Journal of Islamic Marketing Vol. 7 No. 4, pp. 495-507.

Kalamas, M., Cleveland, M., \& Laroche, M. (2014). Pro-environmental behaviours for thee but not for me: Green giants, green gods, and external environmental locus of control. Journal of Business Research Vol. 67 No. 2, pp. 12-22.

Kirmani, M., \& Khan, M. (2016). Environmental concern to attitude towards green products:evidences from India. Serbian Journal of Management, Vol. 11 No. 2, pp. 159-179.

Laroche, M., Bergeron, J., \& Barbaro-Forleo, G. (2001). Targeting consumers who are willing to pay more for environmentally friendly products. Journal of Consumer Marketing,Vol.18 No. 6, pp. 503-520.

Laroche, M., Toffoli, R., K. C., \& Muller, T. (1996). The influence of culture on pro-environmental knowledge, attitudes, and behaviour: a Canadian perspective. Advances in Consumer Research,Vol. 23 No. 1, pp. 196-202.

Moser, A. (2015). Thinking green, buying green? Drivers of pro-environmental purchasing behaviour. Journal of Consumer Marketing, Vol. 32 No. 3, pp. 167-175. 
Muralidharan, S., Rejón-Guardia, F., \& Xue, F. (2015). Understanding the Green Buying Behavior of Younger Millennials from India and the United State. Journal of International Consumer Marketing Vol. 28 No. 1, pp. 54-72.

Nath, V., Kumar, R. A., R., G. A., \& Sharma, V. (2013). impediments to adoption of green products: an ism analysis, Journal of Promotion Management, Vol. 20 No. 5, pp. 501-520.

Nguyen, T. N., Greenland, S., \& Lobo, A. (2017). The Influence of Cultural Values on Green Purchase Behaviour. Marketing Intelligence \& Planning Vol. 35 NO.3, pp. 377-396.

Ogbeide, 0. F., \& Stringer, R. (2015). The environmental benefits of organic wine: Exploring consumer willingness to pay premiums? Journal of Food Products Marketing, Vol. 21 No. 5, pp. 482-502.

Parsian, N., \& Dunning, T. (2009). Developing and Validating a Questionnaire to Measure Spirituality: A Psychometric Process. Global journal of health science Vol.1No.1.

Rahbar, E., \& Wahid, N. A. (2011). Investigation of green marketing tools' effect on consumers' purchase behavior. Business Strategy Vol. 12 No.2, pp.73-83.

Ratnakar, R., \& Nair, S. (2012). A Review of Scientific Research on Spirituality. Business Perspectins and Research.

Razzaque, M. a. (2013). Religiosity and Muslim consumers' decision making process in a nonMuslim society. Journal of Islamic Marketingô, Vol. 4 No. 2, pp. 198-217.

Tang, C., \& Lam, D. (2017). The role of extraversion and agreeableness traits on Gen Y's attitude and willingness to pay for green hotels. International Journal of Contemporary Hospitality Management, Vol. 29 No. 1, pp. 607-623.

Tang, Y., Wang, X., \& Lu, P. (2014). Chinese consumer attitude and purchase intent towards green products. Asia-Pacific Journal of Business Administration, Vol. 6 No. 2, pp. 84-96.

Zhao, H., Gao, Q., Wu, Y., Wang, Y., \& Zhu, X. (2014). What affects green consumer behavior in China? A case study from Qingdao. Journal of Cleaner Production, Vol. 63 No. 1, pp. 143-151.

Zinkhan, G. M., \& Carlson, L. C. (1995). Green advertising and the reluctant consumer. Journal of Advertising, 1-6. 